\author{
Małgorzata DOWLASZEWICZ \\ ORCID: 0000-0002-2512-1381 \\ Uniwersytet Wrocławski \\ Jacek KARPIŃSKI \\ ORCID: 0000-0003-2712-0638 \\ Uniwersytet Wrocławski
}

\title{
Op reis naar de kleurrijke wereld van taal, literatuur en cultuur...
}

"Je kunt de vele talen van Europa beschouwen als een hindernis voor de reiziger. Net zoals je de Alpen kunt zien als een hindernis op weg naar Italië" - schreef in 2012 taaljournalist Gaston Dorren. Maar alle talen, alle culturen en alle literaturen zijn zoals de Alpen "juist bezienswaardigheden om je eindeloos over te verbazen en ademloos aan te vergapen. Elke dag open, toegang gratis" (Dorren 2012).

Literatuur over reizen beslaat verslagen van bedevaarten, VOC-journalen, koloniale literatuur of reportages. Maar de literatuur zelf reist ook: ze wordt bijvoorbeeld naar andere talen vertaald. Het onderzoek naar de betekenis van deze vertalingen, maar ook naar de rol van de vertaler is een van de leidende richtingen in de internationale neerlandistiek van de afgelopen jaren. En ook de taal zelf reist: in de tijd (veranderingen, evolutie), in de ruimte (culturele problemen bij de vertaling, verschillen en overeenkomsten tussen talen) en soms in allebei.

De gespecialiseerde taal die gebruikt wordt op reis, in de toeristische branche of in teksten over reizen, lijkt in veel aspecten heel apart te zijn. De gebruikte terminologie is er een bewijs van. Ook mag men de talige en buitentalige elementen niet vergeten, die bijvoorbeeld de communicatie in de toeristische sector vergemakkelijken.

Gebleken is dat toerisme eveneens een rijke bron van inspiratie voor het (intercultureel) onderwijs vormt. Les geven buiten het leslokaal, samen met stu- 
denten hun eigen stad in het Nederlands exploreren, dat zijn methodes, die steeds meer aanhangers in de regio lijken te hebben. En hoe doceert men toeristisch Nederlands? Welke onderwerpen moeten in de lessen vaktaal aan bod komen?

Om deze (en vele andere) vragen te beantwoorden vond in mei 2017 een bijzondere reis in de Centraal-Europese neerlandistiek plaats - de reis naar de kleurrijke wereld van taal, literatuur en cultuur. Het programma van het Comenius Regionaal Colloquium Neerlandicum met rond 90 sprekers heeft een brede waaier aan onderwerpen getoond met het overkoepelend thema van de reis. Dit speciale nummer van het tijdschrift presenteert een keuze van de bijdragen die tussen 24 en 27 mei 2017 in Wrocław werden gepresenteerd. Het getuigt niet alleen van zeer uiteenlopende belangstelling van de Centraal-Europese neerlandistiek, maar nog meer van een hoog wetenschappelijk niveau op het gebied van taal- en letterkunde, vertaalkunde, didactiek en culturele studies. Konvička en Pekelder nemen de lezer mee op de reis binnen de taal. In zijn artikel toont Konvička hoe mede dankzij de verbreiding van de sociale media het gebruik van 'want' en 'omdat' verandert. Hij stelt zich de vraag naar de vaagheid van linguïstische categorieën. De bijdrage van Pekelder laat zien dat er goede redenen bestaan om de tientallen principes, die in de vakliteratuur met betrekking tot constituentenvolgorde worden voorgesteld, zijn terug te voeren op drie basisprincipes: het iconisch principe, het grammaticaal principe en het situationeel principe. Křiž en Rombouts dragen veel bij tot het moderne NVT-onderwijs. Křiž reist naar de boeiende wereld van muziek en poëzie en presenteert het door hem persoonlijk herontdekte potentieel van gedichten en liedjes voor het vergroten van de verbeeldingskracht van de studenten en het vergroten van hun woordenschat. Rombouts daarentegen stelt een alternatieve reisgids als didactische methode voor. Štefková en Waterlot houden zich bezig met het belang van vertalen en tolken binnen de opleidingen Nederlands in Centraal-Europa. Štefková besteedt haar aandacht aan het begrip 'communicty interpreting' en de verandering van de maatschappelijke context en de nood aan gekwalificeerde tolken geschetst in verband met de migratiebewegingen binnen de EU. Waterlot presenteert het belang van vertalen in het vreemdetaalonderwijs. De linguïstische reis wordt afgesloten met een opiniestuk van Steurs over de nieuwe trends in de toepassingen van de taalkunde omdat er door een aantal belangrijke maatschappelijke ontwikkelingen een nieuwe visie op taal ontstaat.

Een van de meest vanzelfsprekende literaire uitingen waarin een reis centraal staat, zijn reisbeschrijvingen. Engelbrecht analyseert het beeld van Nederland en de Nederlanders in de Tsjechische reisverslagen door de eeuwen heen. Behalve de clichéachtige beelden van een land dat tegen water moet vechten, vindt men daar ook verwijzingen naar een veel modernere problematiek, zoals de positie van de vrouw in de maatschappij. Reisverslagen, maar dan alleen uit de tijden van de Nederlandse Republiek, hebben ook de wetenschappelijke belangstelling van Nij- 
enhuis-Bescher getrokken. In zijn artikel presenteert hij de moeilijke Frans-Nederlandse betrekkingen in deze periode vanuit het Franse perspectief. Ook het artikel van Kuznik concentreert op teksten die ingevolge van een verre reis zijn ontstaan. Ze duikt niet alleen in de manier waarop Japan in het Nippon van von Siebold werd gepresenteerd, maar ook in de mate waarin de Japanners een rol in het ontstaan van de tekst hebben gespeeld.

Een ander aspect is de manier waarop teksten of verhalen 'reizen', hoe ze op verschillende manieren worden gerecipieerd, vertaald, bewerkt. Đokanović analyseert de manier waarop Willem Brakman in zijn roman Een vreemde stam heeft mij geroofd het mythische verhaal over de Argonauten bewerkt, welke nieuwe betekenissen aan de bekende elementen worden toegevoegd en welke nieuwe lagen ervan worden weergegeven. Sedláčková toont op welke manier toneelteksten uit de Nederlanden in Tsjechië werden vertaald en bewerkt, maar richt zich nog meer op de vraag waarom tamelijk weinig Nederlandse toneelstukken Tsjechische receptie kenden.

Niet alleen de teksten zelf maar ook ideeën kunnen verbonden zijn met geografische verplaatsing. Srebnik discuteert de manier waarop een Oost-Europees idee door een Nederlandse kunstenaar werd eigengemaakt. De X-Beelden van Van Doesburg worden tegen de achtergrond van de constructivistische postulaten gelezen. In het artikel van Stoicescu worden we ondergedompeld in de groteske van Paul van Ostaijens werk dat naar aanleiding van zijn verblijf in Berlijn is ontstaan. Stoicescu analyseert onder andere hoe de stad in de teksten werd verbeeld. Dimitrova stelt vragen over een tegenwoordig zeer belangrijke kwestie van vluchtelingen die tijdens een tocht hun identiteit langzamerhand onthullen en verbindt aan de identiteitsbepaling een contextuele voorwaarde die in het werk van Wieringa zichtbaar wordt.

Laten we samen op reis gaan naar de kleurrijke wereld van taal, literatuur en cultuur die ons omringt. De route kan je zelf bepalen... 